DOI: 10.32844/2222-5374-2020-104-2.23

УДК: 342.9

Кучеренко I. Г.,

здобувач Науково-дослідного інституту публічного права

\title{
ФОРМИ ТА МЕТОДИ КОНТРОЛЬНО-НАГЛЯДОВОЇ ДІЯЛЬНОСТІ У СФЕРІ ПУБЛІЧНИХ ЗАКУПІВЕЛЬ
}

Мета статті полягає в тому, щоб на основі чинного законодавства, що регулює контрольно-наглядову діяльність у сфері публічних закупівель в Україні, позиції практиків та вчених адміністративного права визначити та проаналізувати форми та методи вказаної діяльності у визначеній сфері. у статті аналізується чинне законодавство України та погляди науковців-адміністративістів щодо визначення поняття, класифікації форм та методів контрольно-наглядової діяльності у сфері публічних закупівель. Вадміністративно-правовій науці існує два підходи до розуміння категорії «адміністративно-правова форма» які використовуються при характеристищі діяльності у сфері виконавчої влади. Відповідно до широкого підходу, зовні виражені дії (форма) притаманні не тільки органу виконавчої влади (суб'єкту державного управління), а й іншим суб'єктам адміністративного права - громадянам, громадським об'єднанням тощо, представники вузького підходу вважають, що адміністративно-правова форма характерна лише для діяльності органів виконавчої влади. Автором доводиться, що широкий підхід до трактування «адміністративно-правової форми» є виправданим, адже адміністративна наука вже давно почала відходити від "радянського» ставлення до адміністративної діяльності, як суто діяльності органів виконавчої влади з використанням своїх владних повноважень. Рух в сторону сервісності та більш широкого залучення громадського сектору для прозорої та ефективної діяльності різних суб'єктів адміністративної діяльності взагалі та суб'єктів контрольно-наглядової діяльності - зокрема, обумовило обрання вказаного вектору. Визначається, що особливістю вчинення юридично значущих дій суб'єктами контрольно-наглядової діяльності у сфері публічних закупівель $\epsilon$ те, що вони в основному вчиняються за допомогою електронної платформи «ProZorro» та інших інформаційних ресурсів. В свою чергу методами контрольно-наглядової діяльності у вказаній сфері $\epsilon$ сукупність конкретних прощедурно-процесуальних дій (позитивного та примусового характеру), які використовуються на всіх стадія публічної закупівлі та передують закріпленню результатів діяльності контролюючих суб'єктів.

Ключові слова: метод, форма, нормативно-правовий акт, адміністративний договір, публічні закупівлі.

Актуальність теми. Сучасний стан розвитку держави характеризується появою нових актуальних теоретичних і практичних 
проблем, які широко обговорюються й стають предметом дискусій як серед науковців, так і практичних працівників [1, с. 188]. Одним із таких питань $є$ визначення форм та методів контрольно-наглядової діяльності у сфері публічних закупівель.

Осмислення теоретичних та практичних аспектів форм та методів контрольно-наглядової діяльності у сфері публічних закупівель зумовило необхідність в проведені наукових досліджень у вказаній сфері. Крім того, про теоретичну та практичну важливість даного питання, необхідність вирішення наукових проблем у даній сфері свідчить увага міжнародних організацій.

Огляд останніх досліджень. Проблеми адміністративно-правових форм і методів досліджували: В. Авер'янов, В. Галунько, В. Колпаков. В. Красногор, В. Курило, В. Мурза, Н. Попова та ін. При цьому, практичні проблеми в сфері контрольно-наглядової діяльності публічних закупівель в Україні зумовлюють необхідність детального розгляду окремих питань аналізованої тематики.

Мета статті полягає в тому, щоб на основі чинного законодавства, що регулює контрольно-наглядову діяльність у сфері публічних закупівель в Україні, позиції практиків та вчених адміністративного права визначити та проаналізувати форми та методи вказаної діяльності у визначеній сфері.

Виклад основного матеріалу. Для того, щоб схарактеризувати основні форми контрольно-наглядової діяльності суб’єктів контрольнонаглядової діяльності у сфері публічних закупівель, потрібно з'ясувати термінологічний апарат. Так, великий тлумачний словник сучасної української мови під «формою» розуміє: «спосіб існування змісту його внутрішня структура, організація і зовнішній вираз» [2, с. 1328]. Тобто, форма передбачає єдність внутрішньої її будови із зовнішнім проявом в об’єктивній дійсності.

Розглядаючи форми діяльності як особливий структурний елемент правового статусу органів публічної влади, розмежовують правові та організаційні форми їх діяльності залежно від характеру породжуваних наслідків. У новітній юридичній літературі відзначається, що характер форм діяльності конкретного органу визначається «природою суб'єкта державної влади і його компетенцією в галузі здійснення державновладних повноважень» [3; 4, с. 252]. Під формами діяльності органів виконавчої влади в адміністративно-правовій науці найчастіше розуміють зовні виражені дії органу виконавчої влади (посадової особи), що здійснюються в рамках його компетенції і викликають певні наслідки [5, с. 47].

Зокрема, форми діяльності публічної адміністрації, на думку В. Галунька, - це зовнішнє вираження однорідних за своїм характером і правовою природою груп адміністративних дій суб'єктів публічної адміністрації, здійснене в рамках режиму законності та компетенції для досягнення адміністративно-правової мети - публічного забезпечення прав і свобод людини і громадянина, нормального функціонування громадянського суспільства й держави. За характером і правовою природою форми діяльності суб’єктів публічної адміністрації поділяються на видання адміністративних актів (підзаконних нормативно-правових актів, 
індивідуальних адміністративних актів); укладення адміністративних договорів; учинення інших юридично значущих адміністративних дій; здійснення матеріально-технічних операцій [6, с. 103; 7].

Також існує і більш широкій підхід до визначення категорії «адміністративно-правова форма», який використовується при характеристиці діяльності у сфері виконавчої влади. Відповідно до широкого тлумачення, зовні виражені дії (форма) притаманні не тільки органу виконавчої влади (суб'єкту державного управління), а й іншим суб'єктам адміністративного права - громадянам, громадським об'єднанням тощо.

На нашу думку, широкий підхід до трактування «адміністративноправової форми» $є$ виправданим, адже адміністративна наука вже давно почала відходити від «радянського» ставлення до адміністративної діяльності, як суто діяльності органів виконавчої влади з використанням своїх владних повноважень. Рух в сторону сервісності та більш широкого залучення громадського сектору для прозорої та ефективної діяльності різних суб'єктів адміністративної діяльності взагалі та суб'єктів контрольно-наглядової діяльності - зокрема, обумовило обрання вказаного вектору. Тому, визначення форми діяльності як «реальні, видимі, типізовано фіксовані вирази (прояви) практичної діяльності управлінців» $[8$, с. 356], на нашу думку, є більш вдалим і більш підходящим в рамках нашого дослідження.

Таким чином, характеризуючи широкий підхід до аналізованої нами категорії необхідно уточнити, що будь-які специфічні адміністративноправові форми діяльності громадян і громадських об'єднань не виділяються, а вся сукупність адміністративно-правових форм зводиться до видання правових актів управління, укладенню адміністративних договорів, здійсненню організаційних дій і виконанню матеріальнотехнічних операцій [9, с. 224; 10].

Попри відсутності одностайності серед науковців щодо класифікації формадміністративноїдіяльності, науковоюдоктриною виділено двігрупи форм діяльності суб’єктів публічної адміністрації: правові та організаційні, де правові форми - це форми діяльності, які безпосередньо викликають правові наслідки, пов'язані з установленням або застосуванням норм права; організаційні ж форми діяльності суб'єктів публічної адміністрації - це форми, безпосередньо не пов'язані з правовими наслідками [11]. У свою чергу до організаційних заходів слід віднести роз'яснювальну роботу серед населення, правову пропаганду, організаційну допомогу громадським формуванням, взаємодію із засобами масової інформації. Сюди ж належить і видання адресних довідок, узагальнення й розповсюдження передового досвіду, проведення зборів, семінарів, нарад, конференцій [12; 13].

Щодо правових форм контрольно-наглядової діяльності у сфері публічних закупівель, то на нашу думку, провідне місце серед інших займає саме адміністративна нормотворчість суб'єктів контрольнонаглядової діяльності аналізованої сфери, яка полягає у виданні загальних (підзаконних) та індивідуальних актів, які у свою чергу будуть основою для реалізації адміністративних методів їх діяльності. Адже, за допомогою 
видання адміністративних актів, здійснюється адміністративно-правове забезпечення організації та діяльності контролюючих суб'єктів у сфері публічних закупівель. Тобто необхідно проаналізувати загальне та спеціальне законодавство, в тому числі адміністративно-правові акти, що регулюють питання забезпечення реалізації контрольно-наглядової діяльності у вказаній сфері.

Базовий закон, який деталізується підзаконними актами Кабінету Міністрів України, Мінекономрозвитку та наказами інших суб'єктів контрольно-наглядової діяльності у сфері публічних закупівель - це Закон України «Про публічні закупівлі».

Прикладом підзаконних актів є: постанова Кабінету Міністрів України від 24.02.2016 № 166 «Про Порядок функціонування електронної системи закупівель та проведення авторизації електронних майданчиків». Вказаний Порядок визначає вимоги до функціонування електронної системи закупівель, процедуру проведення авторизації електронних майданчиків, умови підключення та випадки відключення електронних майданчиків від електронної системи закупівель, вимоги до електронних майданчиків та відповідальність операторів авторизованих електронних майданчиків [14]; наказ Міністерства розвитку економіки, торгівлі та сільського господарства України від 07.04.2020 № 648 «Про веб-портал Уповноваженого з питань закупівель», в якому з метою вдосконалення Закону України «Про публічні закупівлі» було визначено інформаційно-телекомунікаційну систему «ProZorro» (за адресою в мережі Інтернет: www.prozorro.gov.ua) веб-порталом Уповноваженого органу з питань закупівель та визначити відповідальним за забезпечення функціонування та наповнення веб-порталу Державне підприємство «ПРОЗОРРО» [15]; наказ Державної аудиторської служби України від 23 квітня 2018 р. № 86 «Про затвердження форми висновку про результати моніторингу закупівлі та порядку його заповнення» [16]. В свою чергу прикладом індивідуального акту можуть бути: рішення Постійно діючої адміністративної колегії Антимонопольного комітету України з розгляду скарг про порушення законодавства у сфері публічних закупівель; накази Державної аудиторської служби України про початок моніторингу закупівель тощо.

Відповідно до повноважень різних контролюючих органів використання різних форм контролю $\epsilon$ комплексною системою, що дозволяє суб'єктам контрольно-наглядової діяльності в повному обсязі одержувати необхідні відомості про стан діяльності підконтрольних об'єктів, наприклад, органів виконавчої влади у сфері публічних закупівель; виявляти відхилення від установлених нормативними правовими актами вимог, правил, порядку провадження діяльності підконтрольними об’єктами, одержання ними в результаті діяльності належних результатів; вживати заходів із попередження і припинення порушень, відновлення й реалізації порушених вимог, невиконаних рішень, а також уживати передбачених законодавством адекватних виявленим порушенням у ході контрольно-наглядових заходів для притягнення до відповідних видів відповідальності осіб, винних у допущених порушеннях [17, с. 23; 18, с. 111]. 
Отже, підзаконні акти врегульовують загальні питання якості та ефективності проведення контрольно-наглядової діяльності у сфері публічних закупівель, а індивідуальні адміністративні акти $\epsilon$ персоніфікованими та видаються на підставі здійснених суб'єктами контрольно-наглядових заходів: 1) перевірки; 2) аудиту; 3) ревізії; 4) моніторингу; 5) експертизи тощо.

Таким чином, адміністративно-правові акти суб'єктів контрольнонаглядової діяльності у сфері публічних закупівель характеризуються такими ознаками: $€$ підзаконними нормативно-правовими актами, що деталізують закони України в першу чергу Закон України «Про публічні закупівлі»; наділені якісною нормативністю, іншими словами мають виконуватися вказаними суб'єктами та пов'язаними з ними особами; $\epsilon$ обов'язковими для виконання та захищені від порушення засобами адміністративного примусу i кримінального покарання; видаються виключно компетентними суб'єктами контрольно-наглядової діяльності; $\epsilon$ офіційними нормативними актами, проходять визначену законодавством реєстрацію та офіційне оприлюднення; мають бути належно оформлені за правилами юридичної техніки та прийняті з дотриманням нормативно встановлених процедур [19, с. 8; 10].

Адміністративний договір, це спільний правовий акт суб'єктів владних повноважень або правовий акт за участю суб'єкта владних повноважень та іншої особи, що грунтується на їх волеузгодженні, має форму договору, угоди, протоколу, меморандуму тощо, визначає взаємні права та обов'язки його учасників у публічно-правовій сфері і укладається на підставі закону: а) для розмежування компетенції чи визначення порядку взаємодії між суб'єктами владних повноважень; б) для делегування публічно-владних управлінських функцій; в) для перерозподілу або об'єднання бюджетних коштів у випадках, визначених законом; г) замість видання індивідуального акта; г) для врегулювання питань надання адміністративних послуг [20; 21, c. 89].

Ю. Легеза, в межах свого дослідження, зазначає, що адміністративні договори у сфері використання природних ресурсів $\epsilon$ тією унікальною формою публічного управління, що здатна вирішити такі проблеми, як: 1) дублювання повноважень суб'єктів публічного управління загальнонаціонального та регіонального рівнів; 2) підвищення ефективності надання публічних послуг [22].

Щодо предмету нашого дослідження, то як приклададміністративного договору який використовується у сфері публічних закупівель можна навести наступні меморандуми між державними органами тагромадськими інституціями: Меморандум щодо побудови в Україні прозорої та ефективної системи державних закупівель між ДП НАЕК «Енергоатом» та «Прозорі Закупівлі» Громадянської Платформи «Нова Країна» [23]; Меморандум про взаєморозуміння щодо публічних закупівель між Харківською обласною державною адміністрацією та громадськими організаціями «Харківський антикорупційний центр» та «Розвиток публічних закупівель» [24].

На жаль, у сфері публічних закупівель адміністративні договори для врегулювання контрольно-наглядової діяльності у вказаній сфері майже не використовуються та позбавляти приналежності такої 
адміністративно-правової форми до регулювання вказаної діяльності не можна.

Вчинення юридично значущих дій як адміністративно-правова форма контрольно-наглядової діяльності усфері публічнихзакупівель, переважно, розглядається як діяльність, що здійснюється на підставі законів та інших підзаконних нормативних актів та спрямована на виникнення певних юридичних наслідків та до таких дій віднесено державну реєстрацію, видання офіційних документів, складання адміністративного протоколу тощо [25, с. 176-178; 10].

Необхідно зазначити, що особливістю вчинення юридично значущих дій суб'єктами контрольно-наглядової діяльності у сфері публічних закупівель $є$ те, що вони в основному вчиняються за допомогою електронної платформи «ProZoro» та інших інформаційних ресурсів. Так, наприклад, уся тендерна документація, процедура закупівлі, скарги на дії учасників процедури закупівлі, відповіді на скарги, повідомлення про початок моніторингу та його результати подаються в електронному вигляді на офіційному сайті «https://prozorro.gov.ua/».

Здійснення організаційних дій - це різноманітні заходи, які проводяться 3 метою вдосконалити роботу персоналу публічної адміністрації, підняти рівень організації праці і виконавчої дисципліни, втілити позитивний досвід і новітні технології. Водночас вони можуть використовуватися для певного впливу на громадські структури i громадян. Ці дії безпосередньо не спричиняють юридичних наслідків. До таких дій можна віднести різні інструктування, наради, семінари, збори, конференції, надання практичної допомоги, розповсюдження позитивного досвіду, проведення контрольних заходів, вивчення громадської думки, розробка заходів щодо впровадження новітніх досягнень науки і техніки тощо [26, с. 102-103].

Прикладом такої діяльності $є$ проведення аналізу та опублікування «Звіту про результати аналізу щорічного звіту Міністерства розвитку економіки, торгівлі та сільського господарства України, що містить аналіз функціонування системи публічних закупівель та узагальнену інформацію про результати здійснення контролю у сфері закупівель» [27].

Таким чином, здійснення організаційних дій $€$ факультативною формою адміністративної діяльності суб'єктів контрольно-наглядової діяльності у сфері публічних закупівель, що полягає в здійсненні упорядкованих та освітньо-просвітницький дій 3 метою висвітлення та використання ефективного досвіду, вироблення нових механізмів правового регулювання, інформування населення про результати проведення контрольно-наглядової діяльності, а також надання методичної допомоги в цій сфері.

Отже, під методами контрольно-наглядової діяльності у сфері публічних закупівель ми розуміємо сукупність компетенційних повноважень з прийняття підзаконних та індивідуальних актів, укладання адміністративних договорів та інших організаційних дій 3 метою недопущення порушень у вказаній сфері.

Розглядаючи питання про реалізацію (здійснення) контрольнонаглядової функції держави, не можна обійти питання про методи 
державного контролю й нагляду, під якими варто розуміти сукупність засобів і способів контрольно-наглядової діяльності держави [28, с. 119]. В Мурза, вважає, що комплексний, узагальнений характер методів примусу й переконання робить зайвим вирізнення імперативного, диспозитивного, заохочувального й рекомендаційного методів як самостійних. Владно-примусові, імперативні за характером дії органів влади цілком укладаються в рамки методу примусу, а заохочення, стимули, рекомендації та юридична можливість вибирати цілком відповідають елементам методу переконання [18]. Тобто, основними методами адміністративної діяльності виступають: переконання та примус.

Ми частково підтримує вказану позицію, адже метод заохочення не можна ототожнювати із переконанням. Адже, разом з переконанням та примусом заохочення у сфері державного управління застосовується для забезпечення: 1) моделювання взаємодії всіх учасників правовідносин у сфері державного управління; 2) цілеспрямованості впливу суб'єктів владних управлінських повноваженьна об'єкт управління; 3) правомірності поведінки учасників відносин, що виникають у сферах державного управління, у тому числі у сфері реалізації адміністративно-правового статусу публічними службовцями і приватними особами; 4) належного функціонування i захисту режиму законності через підвищення правосвідомості учасників правовідносин [29, с. 7-8; 22].

За допомогою заходів переконання стимулюється належна поведінка учасників адміністративно-правових відносин. Переконання виявляється у використанні різних роз'яснювальних, виховних, організаційних заходів для формування волі суб'єктів адміністративного права або їі корекції. Тим самим особи добровільно підпорядковуються юридичним приписам і свідомо беруть участь в їх виконанні. Для переконання характерним $\epsilon$ таке: воно використовується постійно і стосовно всіх осіб, що перебувають у зоні впливу суб'єктів публічної адміністрації; забезпечують добровільне виконання правових норм, законних вказівок, приписів публічної адміністрації; зрештою виховує правові переконання об’єктів публічного управління та «звичку» свідомо дотримуватись правових норм. Переконання - це процес послідовно здійснюваних дій, який включає такі елементи: оволодіння увагою; навіювання; вплив на свідомість; управління емоціями; формування інтересу. До первинних його засобів належать навчання, пропаганда, агітація, роз'яснення, обмін досвідом. Тобто, переконання - метод адміністративного права, який полягає в попередженні правопорушень шляхом впливу на свідомість і поведінку людей, у результаті чого ті свідомо дотримуються правових норм. Найпоширеніші форми його використання публічною адміністрацією: 1) здійснення систематичної роз'яснювальної роботи щодо норм адміністративно-правових актів (агітаційно-пропагандистська робота); 2) критика антигромадських вчинків; 3) інформування населення про стан забезпечення правопорядку; 4) заохочення громадян, які беруть участь в охороні правопорядку [6, с. 141-148; с. 345; 22].

Прикладом використання методу переконання $\epsilon$ проведення брифінгів, наприклад, ДАСУ провів брифінг на тему «Контроль у сфері закупівель. Річниця запровадження електронного моніторингу. 
Результати, проблеми, перспективи», крім вказаного брифінгу ДАСУ за участю громадських організацій провив круглий стіл з метою обговорення положень Закону України «Про публічні закупівлі» та вироблення єдиних шляхів їх упровадження для підвищення дієвості контролю у сфері закупівель. Також посадовими особами ДАСУ було надано понад 15 інтерв'ю, коментарів, зокрема, засобам масової інформації: 1+1, «24» телеканал новин, NewsOne, «КонсалтІнфо», Радіо Свобода тощо. Організовано зустріч щодо заслуховування звіту 3 моніторингу публічних закупівель в Україні, здійсненого проектом ЄС «Підтримка реалізації стратегії реформи публічних закупівель для гармонізації в Україні», за участі представників Представництва ЄС в Україні, КМУ, Мінекономрозвитку, ДП «Прозорро», Transparency International Ukraine, DataPathAnalytics та інших [30, с. 158].

Як зазанчає А. Комзюк, примус застосовують на основі переконання до тієї частини громадян, які порушують чинні норми й правила, i проявляється він у притягненні винного в скоєнні правопорушення до того чи іншого виду юридичної відповідальності. Цілеспрямований характер застосування адміністративного примусу зумовлює його дієвість, оскільки суспільство в будь-який період свого існування передбачає використання примусу щодо особи для блага всього населення [31, с. 67; 32, с. 32].

19 квітня 2020 року набули чинності зміни до законодавства про публічні закупівлі, які вплинули і на порядок роботи суб’єктів контрольно-наглядової діяльності. Так, набула чинності нова редакція ст. 164-14 КУпАП, яка розширила перелік порушень, які передбачають адміністративну відповідальність, та збільшила суми штрафів. Для частини правопорушень зменшився строк накладання стягнень 3 трьох до двох місяців. Для інших збільшився з трьох місяців до шести. На практиці це означатиме, що порушників з більшою вірогідністю притягнуть до відповідальності. Окрім цього, розгляд частини правопорушень було забрано в судів та передано ДАСУ. Таким чином, щодо частини порушень постанови про притягнення до відповідальності тепер будуть виносити самі аудитори [33]. За результатами проведення заходів державного фінансового контролю міжрегіональними територіальними органами ДАСУ протягом 2019 року в рамках реалізації їх результатів в частині притягнення посадових осіб підконтрольних установ до адміністративної відповідальності за ст. 164-14 КУпАП посадовими особами міжрегіональних територіальних органів складено 881 протоколів про адміністративні правопорушення, що потягло за собою притягнення до відповідальності 114 винних осіб та стягнуто у державний бюджет штрафу на суму 833 тис. грн.[30].

Аналіз систематизації базових положень та визначених вище підходів дає змогу різнобічно підійти до розв'язання проблемних питань щодо форм і методів контрольно-наглядової діяльності у сфері публічних закупівель. Будь-який метод повинен зовні виявлятися у якійсь формі, а форма, у свою чергу, може існувати лише тоді, коли наповнена відповідними методами. Тобто, форма - це зовнішній прояв (результат) конкретних контрольних або наглядових процесуальних та організаційних дій, який зримо виявляється в певних актах за результатами діяльності перевіряючих (актах перевірки, ревізії, приписах або постанова прокурора та ін.), а метод 
- сукупність конкретних процесуальних дій, які передують формальному закріпленню результатів» [34].

Висновки. Отже, під адміністративно-правовою формою контрольнонаглядової діяльності у сфері публічних закупівель ми розуміємо сукупність компетенційних дій з прийняття підзаконних та індивідуальних актів, укладання адміністративних договорів та інших організаційних дій 3 метою недопущення порушень у вказаній сфері. В свою чергу методами контрольно-наглядової діяльності у вказаній сфері $є$ сукупність конкретних процедурно-процесуальних дій (позитивного та примусового характеру), які використовуються на всіх стадія публічної закупівлі та передують закріпленню результатів діяльності контролюючих суб'єктів.

\section{СПИСОК ВИКОРИСТАНИХ ДЖЕРЕЛ}

1. Даниленко А. П. Поняття та структура адміністративно-правового статусу органів місцевого самоврядування: теоретико-правовий аспект. Право і суспільство, 2012. № 6. С. 187-190. URL: http://www.pravoisuspilstvo. org.ua/archive/2013/6_2013/41.pdf

2. Великий тлумачний словник сучасної української мови. Укл. і голов. ред. В.Т. Бусел. К.: ВТФ «Перун», 2001. 1440 с.

3. Журавський В.С., Серьогін В.О., Ярмиш О.Н. Державне будівництво та місцеве самоврядування в Україні: підруч. для студ. вищ. навч. закл. К.: Вид. дім «Ін Юре», 2003. 671 с.

4. Опацький Р.М. Форми діяльності публічної адміністрації у сфері реалізації ювенальної політики. Порівняльно-аналітичне право. 2013. № 3-1. С. 252-256.

5. Попова Н.Ф. К вопросу об административно-правовых формах и методах деятельности органов исполнительной власти. Вестник Российского государственного гуманитарного университета. Серия : Юридические науки. 2011. № 8 (70). С. 47-55.

6. Галунько В.В., Курило В.І., Короєд С.О. та ін. Адміністративне право України. Загальне адміністративне право: навчальний посібник. Т.1. Херсон: Грінь Д.С., 2015. 272 с.

7. Лавренікова О. С. Методи реалізації публічного адміністрування будівництва в Україні. Прикарпатський юридичний вісник. 2017. Вип. 1(16). Т. 4. С. $144-147$.

8. Глазунова Н. И. Государственное (административное) управление. М.: ТК Велби ; Проспект, 2004. 560 с.

9. Габричидзе Б. Н., Елисеев Б. П. Российское административное право : учебник для вузов. М.: Норма-Инфра-М, 1998. 622 с.

10. Красногор В. О. Адміністративно-правові форми забезпечення нотаріальної таємниці. Право як ефективний суспільний регулятор: матеріали міжнародної науково-практичної конференції (Львів, 14-15 лют. 2020 р.). Львів: Західноукраїнська організація «Центр правничих ініціатив», 2020. С. 45-47.

11. Елистратов А. И. Административное право: лекции. М. : Тип. т-ва И.Д. Сытина, 1911. 235 с.

12. Бережная I. Г. Нотаріальний процесуальний кодекс повинен стати головним регулятором порядку вчинення нотаріальних дій. Юридична 
газета, 2011. № 10 (8 березня). URL: http://narodna.pravda.com.ua/ politics/4d7e0bf6471cc/

13. Красногор В. О. Організаційно-правові засади забезпечення нотаріальної таємниці Дисертація на здобуття наукового ступеня доктора філософії за спеціальністю 081-Право. - Науково-дослідний інститут публічного права, Науково-дослідний інститут публічного права, Київ, 2020.

14. Про затвердження Порядку функціонування електронної системи закупівель та проведення авторизації електронних майданчиків: Постанова Кабінету Міністрів України від 24.02.2016 р. № 166. Офіційний вісник України. 2016. № 22. С. 13.

15. Про веб-портал Уповноваженого з питань закупівель: Наказ Міністерства розвитку економіки, торгівлі та сільського господарства України від 07.04.2020 р. № 648. URL: https://www.me.gov.ua/LegislativeActs/List?lang=uk-UA\&id=6e190ba6-3c35-4244-8a3f-bc8733ca97de\&tag=NormativnaBaza

16. Про затвердження форми висновку про результати моніторингу закупівлі та порядку його заповнення: Наказ Державної аудиторської служби України від 23 квітня 2018 р. № 86. URL: https://www.dasu.gov.ua/ ua/plugins/userPages/1581

17. Нижник М., Машков О. Контроль у сфері державного управління. Вісник УАДУ, 1998. № 2. С. 23-31.

18. Мурза В. В. Форми та методи державної контрольно-наглядової діяльності. Публічне право. 2013. № 2 (10). С. 110-116

19. Ковальчук С. П. Адміністративно-правове регулювання нотаріальної діяльності в Україні : автореф. дис. ... канд. юрид. наук: 12.00.07. Київ, 2019. 17 с.

20. Кодекс адміністративного судочинства України : Закон України від 06.07.2015 № 2747-IV. Офіційний вісник України. 2005. № 32. С. 11.

21. Повидиш В. В. Адміністративно-правові відносини у сфері електронних публічних закупівель. Науковий вісник публічного та приватного права, 2018. С. 87-93. URL: http://nvppp.in.ua/vip/2018/6/tom_2/19.pdf

22. Сукманова О. В. Публічне адміністрування охорони права власності в Україні: ... док-ра. юрид. наук: 12.00.07. Суми, 2019. URL: https://core.ac.uk/ download/pdf/324228925.pdf

23. Енергоатом підписав меморандум щодо побудови в україні прозорої та ефективної системи державних закупівель, 2014 https://www. energoatom.com.ua/ua/press_centr-19/novini_kompanii-20/p/energoatom_ pdpisav_memorandum_schodo_pobudovi_v_ukran_prozoro_ta_efektivno_ sistemi_derjavnih_zakupvel-1047

24. ХОДА продовжує співпрацю з громадськими організаціями у сфері публічних закупівель, 2020. URL: https://kharkivoda.gov.ua/news/102379

25. Административное право Украины. Под общей ред. С.В. Кивалова. Харьков: Одиссей, 2005. 880 с.

26. Колпаков В. К. Административное право Украины: Учебник. К.: Юринком Интер, 1999. 736 с.

27. Інформаційне повідомлення про виконання рішення Рахункової палати від 30.06.2020 № 15-1. URL: https://rp.gov.ua/FinReactions/?id= 1028 
28. Сушко Л. Зміст контрольної діяльності органів державної влади. Право Украӥни, 2007. № 9. С. 118-131.

29. Козачук Д. А. Заохочувальні адміністративні процедури : автореф. дис. ... канд. юрид. наук : 12.00.07. Одеса, 2010. 18 с.

30. Звіт про результати діяльності Державної аудиторської служби України, її міжрегіональних територіальних органів за 2019 рік. Державна аудиторська служба України, 2019. URL: https://dasu.gov.ua/attachments/ analytical-reports/2019/897f4ba0-b223-4638-93a5-2b7ba5cd1bd3_158169. pdf

31. Комзюк А. Т. Заходи адміністративного примусу в правоохоронній діяльності міліції: поняття, види та організаційно-правові питання. Харків : Нац. ун-т внутр. справ, 2002. 336 с.

32. Дембіцька С. Л. Особливості застосування основних адміністративно-правових методів переконання та примусу. Науковий вісник Міжнародного гуманітарного університету. Серія : Юриспруденція. 2018. Вип. 32. С. 31-34.

33. Тимофеюк А. Публічні закупівлі для новеньких. Transparency International Ukraine, 2020. URL: https://ti-ukraine.org/wp-content/uploads/2020/07 / Derzhaudytsluzhba-v-publichnyh-zakupivlyah-chy-efektyvni-monitoryngy-1.pdf

34. Голоднова Т. С. Контроль як гарантія законності управління майном військових формувань України: адміністративно-правові засади: дис. ... канд. юрид. наук: 12.00.07. Ірпінь, 2019.

\section{Kucherenko}

\section{FORMS AND METHODS OF CONTROL AND SUPERVISION ACTIVITY IN THE FIELD OF PUBLIC PROCUREMENT}

The purpose of the article is to determine and analyze the forms and methods of these activities in a particular area on the basis of current legislation governing control and supervision activities in the field of public procurement in Ukraine, the position of practitioners and scholars of administrative law. The article analyzes the current legislation of Ukraine and the views of scientists-administrators on the definition of the concept, classification of forms and methods of control and supervision in the field of public procurement. In administrative and legal science, there are two approaches to understanding the category of "administrative and legal form» that are used to describe activities in the executive branch. According to the broad approach, outwardly expressed actions (form) are inherent not only in the executive body (subject of public administration), but also in other subjects of administrative law - citizens, public associations, etc., representatives of the narrow approach believe that administrative the legal form is characteristic only for the activity of executive bodies. The author argues that a broad approach to the interpretation of the "administrative-legal form» is justified, because administrative science has long begun to move away from the «Soviet» attitude to administrative activity, as a purely activity of the executive branch using its powers. The movement towards servitude and greater involvement of the public sector for the transparent 
and efficient operation of various administrative entities in general and the subjects of control and supervision - in particular, led to the choice of this vector. It is determined that the peculiarity of the legally significant actions of the subjects of control and supervision in the field of public procurement is that they are mainly performed using the electronic platform «ProZorro» and other information resources. In turn, the methods of control and supervision in this area are a set of specific procedural actions (positive and coercive), which are used at all stages of public procurement and precede the consolidation of the results of the controlling entities.

Keywords: method, form, normative legal act, administrative contract, public procurement. 